\title{
Renal Stem Cells Transplantation in Autosomal Recessive Polycystic Kidney Disease; a Visible Science Fiction
}

\section{Mohamed SA*}

Department of Medicine, University of Cologne, Cologne, Germany

"Correponding author: Mohamed SA, Department of Medicine, niversity of Cologne, 50679, Cologne, Germany, Tel: 4915214736574;mail: mohammed.shehatta1@gmail.com

Rec Date: June 15, 2016; Acc Date: June 23, 2016; Pub Date: June 29, 2016

Copyright: (C) 2016 Mohamed SA. This is an open-access article distributed under the terms of the Creative Commons Attribution License, which permits unrestricted use, distribution, and reproduction in any medium, provided the original author and source are credited.

Citation: Mohamed SA (2016) Renal Stem Cells Transplantation in Autosomal Recessive Polycystic Kidney Disease; a Visible Science Fiction. Gen Med 4: 257.

\section{Introduction}

Autosomal recessive polycystic kidney disease (ARPKD) is a developmental disease that affects 1 in 10000- 40000 live births worldwide. It manifests in the form of disturbed celullar proliferation/ apoptosis that affects the epithelium of the renal collecting ducts and the biliary ducts. Disturbed cellular polarity plays a major role in the disease development, rendering the cyst epithelium secretory rather than absorptive [1]. The main molecular changes of ARPKD are lossof function mutations of Fibrocystin, defective Focal Adhesion Kinase (FAK) activation, and defective $\beta 1 \mathrm{Na}+/ \mathrm{K}+$ ATPase expression [2].

Stem cell therapy could shine as a therapeutic hope, but which and how?

There are 3 types of stem cells;

-Embryonic stem cells, which are derived from the inner cell mass of blastocyst and have the ability to differentiate into cell types of all three germ lineages, but carry high risk of teratoma [3].

-Induced pleuripotent stem cells, which are similar to the embryonic stem cells in the ability to differentiate into cell types of all three germ lineages and the risk of teratoma, but are derived from the somatic cells [3].

Both cell types have high degree of proliferation, self-renewal ability and grow indefinitely.

-Somatic stem cells can be isolated from the adult tissue, are multipotent, with limited self-renewal capacity and limited life span, but with no teratomic risk [3].

In ARPKD, which is a genetic developmental disease, autotransplantation of stem cells would not help because the underlying Fibrocystin mutations are expected to be present in the stem cells. In addition, the infantile age of the patients may potentiate the teratomic risk of pluripotent stem cells. Accordingly, somatic stem cells seem to be of choice, but they can differentiate into limited cell types depending on the tissue of origin.
Renal stem cells have been successfully isolated, which are spindleshaped, capable of self-renewal for $>200$ population doublings with normal karyotype and DNA analysis. They were found to express vimentin, CD90 (thy1.1), Pax -2, and Oct4 but not cytokeratin, MHC class I or II, or other markers of more differentiated cells [4]. These cells have the ability to differentiate into renal tissue and lack surface molecules essential for the stimulation of the immune system, which renders the possibility of allografting from healthy individuals applicable [4].

\section{Future Hope}

The renal stem cells might be isolated from a single or multiple donors through guided renal biopsies, where the renal biopsy could be partially digested by collagenase to obtain cellular suspensions that could be treated and cultured as described by Gupta et al. [4]. The stem cells could be then transplanted and introduced through the renal artery, with the hope of the successful slowdown, stop and or reversal of the cystic formation. Repetition of the procedure at frequent intervals might have a more positive impact, if the intra-renal administration could be developed in a relatively less invasive and more efficient intervention.

\section{References}

1. Katherine M, Dell MS, Ellis D, Avner MD (2014) Polycystic kidney disease, autosomal recessive synonyms: ARPKD/CHF. GeneReviews.

2. Christian R Halvorson, Matthew S Bremmer, Stephen C Jacobs (2010) Polycystic kidney disease: inheritance, pathophysiology, prognosis, and treatment. Int J Nephrol Renovasc Dis 3: 69-83.

3. Carla A Herberts, Marcel SG Kwa, Harm PH Hermsen (2011) Risk factors in the development of stem cell therapy. J Transl Med 9: 29.

4. Sandeep Gupta, Catherine Verfaillie, David Chmielewski, Stefan Kren, Keith Eidman (2006) Isolation and characterization of kidney-derived stem cells. JASN 17: 3028-3040. 